\title{
Temperature Gradient Daily Dynamics Area and Time Zoning for Local Analysis of Air-Water Interaction
}

\section{Christophil S. Medellu}

Manado State University

Alfrits Komansilan ( $\square$ alfritskomansilan@gmail.com )

Department of Physics, Manado State University

\section{Research Article}

Keywords: model adoption, thermal interaction, gradient dynamics, irradiation, SST layer

Posted Date: February 2nd, 2021

DOl: https://doi.org/10.21203/rs.3.rs-155562/v1

License: (c) (1) This work is licensed under a Creative Commons Attribution 4.0 International License.

Read Full License 


\title{
Temperature Gradient Daily Dynamics Area and Time Zoning for Local Analysis of Air-Water Interaction
}

\author{
Christophil S. Medellu ${ }^{1}$ and Alfrits Komansilan ${ }^{2}$ \\ ${ }^{1,2}$ Department of Physics, Manado State University \\ chrismedellu@yahoo.co.id \\ alfritskomansilan@gmail.com
}

\begin{abstract}
This article describes the results of the application of time zoning for air-water thermal interaction, and the temperature gradient daily dynamics area (TGDDA) parameters at six locations with different ecological conditions. The research locations consisted of two locations in lakes, two locations in coastal waters which were affected by fresh water and two locations in coastal waters which were not affected by fresh water. Measurement of air and water temperature was carried out in situ at several vertical positions with logarithmic distances to the water surface. The results of the analysis show that the analysis and modeling of the TGDDA parameters produce the time zoning of thermal interaction and TGDDA that vary between research locations. Repeated measurements on two consecutive days at the same location, resulted in almost the same TGDDA and time zoning duration of air-water thermal interaction. These results suggest that these parameters can be used to characterize air-water interactions. The results of this study serve as references to the chemical analysis of water and biota which is interactive or influenced by the dynamics of air-water thermal interactions.
\end{abstract}

Keywords: model adoption, thermal interaction, gradient dynamics, irradiation, SST layer. 


\section{Introduction}

Many researches on atmosphere-sea interactions have been carried out both on a global and local scale. On a large scale, the study of atmosphere-sea interactions, among others, is related to global warming sea surface cooling, and seasonal variations in response to changes of ocean temperature (Liu et al, 2018). Global thermal conditions interact with local thermal conditions (Augyte et al, 2019). Kunz and Jähne (2018) suggests that the variability of air-sea heat fluxes is not only controlled by the atmosphere variations but is also triggered by SST variations as an intrinsic oceanic variability component. Wang et al (2019) argued that solar irradiation causes thermal conditions of water in the mixed or SST layer. Local scale air-water thermal interaction studies are very important to evaluate changes in sea and fresh water conditions. Local scale air-water thermal interaction analysis can yield descriptions of temporal changes in minute orders and spatial variations with meter resolution (Kunz and Jähne, 2018). The effect of the combination of exposure time with the spectral composition, which varies locally, can result in a mismatch between light and temperature requirements which can lead to decreased seaweed reproduction performance (Bettignies et al, 2018). Local scale air-water thermal interaction studies can explain the daily scale of biological circulation (Ptak et al, 2019 and Solcerova et al, 2018). Ptak et al (2018) stated that water temperature research is very important in the context of lake ecosystem function. Shifts in water temperature outside the range that normally apply in ecosystems can have a negative impact on the health of the aquatic ecosystem as a whole. Woolway et al (2017) suggested that the study of the thermal interaction of air with lake water is related to the calculation of biochemical reactions in water. Solcerova et al (2018) suggest that estimating the energy balance of lake water is very important in evaluating the heating and cooling process of water.

Sea Surface Temperature (SST) is a key parameter for the study of air-sea interactions (Alappattu et al, 2017). Solar irradiation causes sea water temperatures at the surface to a depth of $2 \mathrm{~m}$ below the surface to change on daily and seasonal time scales (Feng et al, 2018). Sunlight penetrates clear water, absorbs it to a certain depth (Osuch et al, 2016). The process of absorption and transmission of radiation energy causes the water temperature in the upper layer of bulk SST to be higher than the layer below it (Sim et al, 2017). Physically, the absorption process causes an exponential decrease of energy with increasing the distance. The temperature gradient at the SST skin-bulk boundary layer changes throughout the day due to irradiation and the mixing processes. Studies on water temperature gradients, among others, were carried out by Ge et al (2017). Ge et al (2017) found that a sharp vertical temperature gradient occurs in the surface layer to a depth of $10 \mathrm{~m}$. The gradient of water temperature changes with time, from hour to hour (Maske et al, 2014). Chu and Fan (2019) used an exponential model to determine the water temperature gradient in the vertical direction. This article presents the results of an analysis of the dynamics of water and air temperature gradients in six locations with varying ecological conditions. We use the Temperature Gradient Daily Dynamic Area (TGDDA) parameter to analyze and explain the local scale air-water thermal interactions. Previously, the TGDDA parameter was used to analyze horizontal thermal diffusion between forest ecosystems and the environment, and between mangrove ecosystems and the environment. The adoption of TGDDA to analyze the thermal interactions of air-water is to assume that the water surface is the boundary plane of the water ecosystem with the air as the environment and vice versa.

\section{Method}

The stages of analysis and modeling of the TGDDA parameters are described in detail in previous articles (Medellu and Tulandi, 2018; Medellu 2019, 2020) as follows:

1) Measurement of air temperature at 5 to 7 position along the transect, 
2) Tabulate the data into a matrix format based on position (line: $x$ ) and time (column: $t$ ), which produces temperature data on the basis of position and time: $\mathrm{T}(\mathrm{x}, \mathrm{t})$

3) Modeling of the temporal function $T(t)$. The temporal function is a sinusoidal function, so its modeling uses the Fourier function modeling mechanism. The form of the Fourier function is:

$$
T(t)=T_{0}+\sum_{m=1}^{N / 2}\left(a_{m} \cos \omega_{m} t+b_{m} \sin \omega_{m} t\right)
$$

To is the daily mean of temperature $\mathrm{T}, \omega_{\mathrm{m}}=2 \pi \mathrm{m} / \mathrm{N}, \mathrm{m}$ is the number of harmonics, $\mathrm{N}$ is the amount of data, $a_{m}$ and $b_{m}$ are the Fourier coefficients. The temporal function varies for each position along the transect. Figure-1 presents an example of a graph of the temporal function of air temperature at the edges and inside of a mangrove forest bordering the open sea. Time enumerator 1 associates with the measuring time at 6:00 a.m. The graph shows that between 5:00 a.m. and around 6:00 p.m., the air temperature at the edges was higher than the temperature inside the mangrove forest. Between 6:00 p.m. and 5:00 a.m. the temperature inside is higher than the temperature at the edge of the mangrove forest.

4) Synchronize data between positions. Data synchronization must be done because measurements between positions are not carried out simultaneously. The modeling mechanism is to enter the time difference between positions into the temporal function and generate new $\mathrm{T}(\mathrm{x}, \mathrm{t})$ data. This stage is a prerequisite for spatial function modeling.

5) Modeling of spatial function. The spatial function is in the form of an exponential function following changes in energy with distance due to the absorption effect. The general form of spatial functions is:

$$
T(x)=k_{1}+k_{2} e^{k_{3-} k_{4} x}
$$

where $\mathrm{k}_{1}, \mathrm{k}_{2}, \mathrm{k}_{3}$, and $\mathrm{k}_{4}$. are constant numbers. The mechanism for determining these four constant numbers uses the following algorithm:

$$
\begin{aligned}
& \frac{T_{0}-T_{1}}{T_{0}-T_{2}}=\frac{\left[\left(e^{k_{4} \cdot X_{2}}\right)\left(e^{k_{4} \cdot X_{1}}-1\right)\right]}{\left[\left(e^{k_{4} \cdot x_{1}}\right) \cdot\left(e^{k_{4} \cdot x_{2}}-1\right)\right]} \ldots \\
& k_{3}=\frac{T_{0}-T_{1}}{1-e^{-k_{4 .} x_{1}}} \text {. } \\
& k_{2}=\frac{T_{0}-T_{1}}{e^{k_{3}}-e^{k_{3}-k_{4} \cdot x_{1}}} \\
& k_{1}=T_{0}-k_{2} \cdot e^{k_{3}}
\end{aligned}
$$

This algorithm requires a minimum of three data pairs: $\left(0, \mathrm{~T}_{0}\right),\left(\mathrm{x}_{1}, \mathrm{~T}_{1}\right)$, and $\left(\mathrm{x}_{2}, \mathrm{~T}_{2}\right)$, where the reference position or position $\mathrm{x}=0$ is the edge of the ecosystem. The spatial functions differ for different times, due to the effects of irradiation, absorption, emission and storage of thermal energy by air and other mediums in the ecosystem and environment. Figure-2 presents a graphical example of a spatial function for three variations of time. At the edge or at the zero position, the three graphics show different slopes or gradients. The steepest gradient occurs at 13:00. 


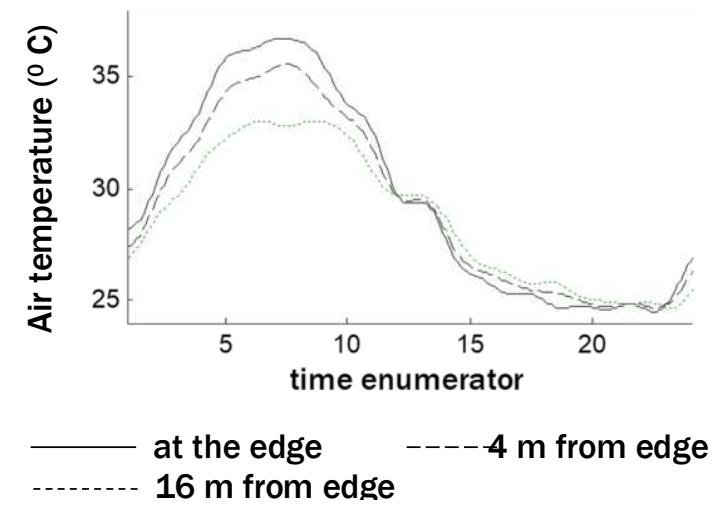

Figure-1. Example of graphic of temporal function of air temperature: transect-2, mangrove forest - Talengen Bay

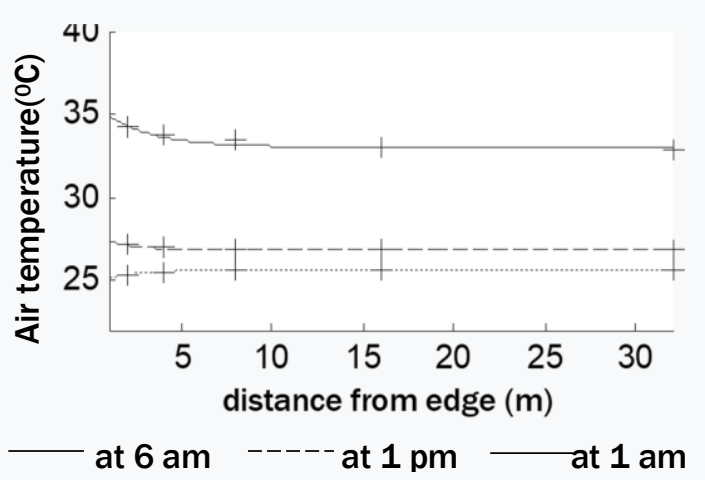

Figure-2. Example of graphic of spatial function of air temperature: transect2, mangrove forest - Talengen Bay

6) Determination of edge gradient values and modeling of gradient dynamics functions. The edge gradient values are obtained by differentiating the spatial function: $\mathrm{dT}(\mathrm{x}) / \mathrm{dx}$, for $\mathrm{x}=0$, resulting in the edge gradient function:

$$
G=\left.\frac{d T(x)}{d x}\right|_{x=0}=-k_{1} \cdot k_{2} \cdot e^{k_{3}}
$$

This edge gradient value changes with time, following changes in the spatial function. The general form of the edge gradient dynamics function is the same as the temporal function so that the modeling follows the Fourier function modeling. The data pairs for modeling gradient dynamics functions are $(t, G(t))$. An example of a graph of the daily dynamic temperature gradient function is presented in Figure-3.

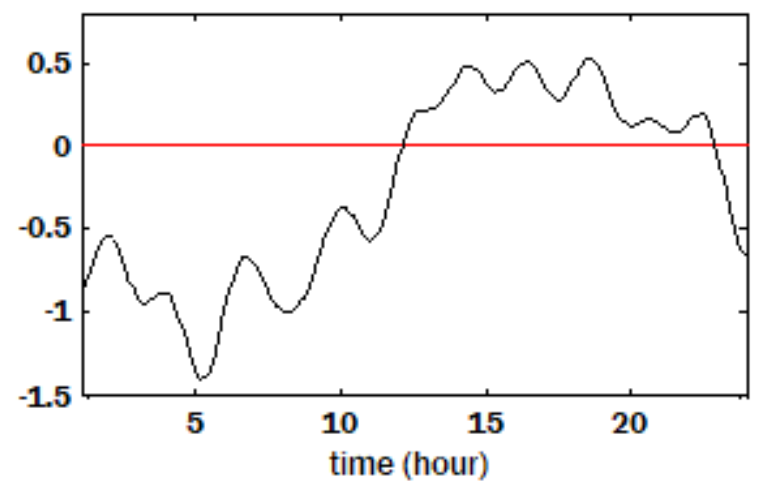

Figure-3. Example of graphic of air temperature gradient dynamic: transect-2, mangrove forest - Talengen Bay

7) Determination of TGDDA, using a numerical integral with the integral limit is the intersection of the gradient dynamics curve with the thermal equilibrium line.

$$
A=\sum_{i=1}^{n}\left|G_{t} \cdot \Delta t\right|
$$


The unit area of TGDDA is ${ }^{0} \mathrm{C}$.hour/m. For the example of Figure-3, the TGDDA under the thermal equilibrium line is $9.69{ }^{0} \mathrm{C}$.hour $/ \mathrm{m}$. This area is bounded by the intersection of the gradient curve with the thermal equilibrium line at 05:00 a.m. and 6:00 p.m. Between 6:00 p.m.. and 05:00 a.m. the gradient curve is above the thermal equilibrium line giving a gradient dynamic area of $3.14{ }^{\circ} \mathrm{C}$. hour $/ \mathrm{m}$.

All stages of analysis and modeling are carried out using software produced by the author in 2012 and have gone through several validation stages. The adoption of the TGDDA parameter to analyze the dynamics of air temperature and water temperature in the vertical direction, as well as air-water thermal interactions, is based on the association:

1) To analyze the dynamics of air temperature gradient, the water surface is the boundary which is considered as the edge.

2) To analyze the dynamics of the water temperature gradient, the subskin-bulk SST boundary is the edge.

3) The air temperature gradient with a positive sign indicates that the air temperature in the upper layer is higher than the temperature near the surface. There is a thermal flux from air to water

4) The air temperature gradient with a negative sign indicates that the air temperature in the near surface layer is higher than the above it. There is a thermal flux from water to air.

5) The zero air temperature gradient shows the air temperature is homogeneous in the vertical direction

6) Positive water temperature gradient indicates that the water temperature in the lower layer is higher than the water temperature near the subskin-bulk SST boundary.

7) The negative water temperature gradient shows that the water in the layer near the subskinbulk SST boundary is higher than the layer below it.

8) The zero water temperature gradient shows the water temperature is homogeneous in the vertical direction

Research location

The study was conducted at six locations with water conditions as presented in Table-1. For locations 1, 2, 5, and 6, measurements were made twice on two consecutive days. For the same location, two sets of data that were generated from two measurements were analyzed separately, and the results were compared to evaluate the consistency of the application of the TGDDA parameters.

Table-1. Measurement location: coordinates and location conditions

\begin{tabular}{|c|c|c|c|c|}
\hline \multirow{2}{*}{$\begin{array}{l}\text { Measure } \\
\text { ment } \\
\text { location }\end{array}$} & \multirow[b]{2}{*}{ Coordinate } & \multirow[b]{2}{*}{ Location conditions } & \multicolumn{2}{|c|}{ Date of measurements } \\
\hline & & & $\mathrm{I}$ & II \\
\hline 1 & $\begin{array}{l}1^{0} 15^{\prime} 15,5 \text { " north, } \\
124^{0} 54^{\prime} 4,6 \text { " east }\end{array}$ & $\begin{array}{l}\text { The shores of Tondano lake, } 3-3.5 \mathrm{~m} \text { deep, } \\
\text { fish farming area, overgrown with weeds }\end{array}$ & $\begin{array}{l}\text { Jan } 5 \\
2019\end{array}$ & $\begin{array}{l}\text { Jan, } 6 \\
2019\end{array}$ \\
\hline 2 & $\begin{array}{l}1^{0} 14^{\prime} 12,1^{\prime \prime} \text { north } \\
124^{0} 54^{\prime} 16,3 \text { " east }\end{array}$ & $\begin{array}{l}\text { In the center of Lake Tondano, the depth is } \\
7-7-5 \mathrm{~m}\end{array}$ & $\begin{array}{l}\text { Jan } 7 \\
2019\end{array}$ & $\begin{array}{l}\text { Jan, } 8 \\
2019\end{array}$ \\
\hline 3 & $\begin{array}{l}3^{0} 35^{\prime} 25,8 \text { " north } \\
125^{0} 33^{\prime} 38,9 \text { '"east }\end{array}$ & $\begin{array}{l}\text { river estuary, } 80 \mathrm{~m} \text { from the coastline } \\
\text { towards the sea, } 1.5 \mathrm{~m} \text { depth at low tide, } 5 \\
\mathrm{~m} \text { at high tide, muddy sand sea floor, } \\
\text { overgrown with seagrass beds }\end{array}$ & $\begin{array}{l}\text { Jan } 15 \\
2019\end{array}$ & - \\
\hline 4 & $\begin{array}{l}3^{\circ} 20^{\prime} 13,92^{\prime \prime} \\
\text { north, } \\
125^{\circ} 35^{\prime} 35,52^{\prime}, \\
\text { east }\end{array}$ & $\begin{array}{l}80 \mathrm{~m} \text { from the shoreline, } 80 \mathrm{~cm} \text { depth at } \\
\text { low tide, } 4,5 \mathrm{~m} \text { meters at high tide, the sea } \\
\text { floor is muddy sand, the beach is } \\
\text { overgrown with mangroves (rarely), natural } \\
\text { growth areas of seaweed (Caulerpa sp.) }\end{array}$ & $\begin{array}{l}\text { Jan } 28 \\
2019\end{array}$ & - \\
\hline 5 & $3^{0} 4$ '17,9"' north & Above coral reef, $120 \mathrm{~m}$ from shoreline, no & August, 8 & August, 9 \\
\hline
\end{tabular}




\begin{tabular}{lllll}
\hline $125^{0} 30^{\prime} 5,7^{\prime \prime}$ east & $\begin{array}{l}\text { river flow, 0-10 cm depth at low tide, } 4 \mathrm{~m} \\
\text { at high tide }\end{array}$ & 2019 & 2019 \\
6 & $3^{0} 4^{\prime} 20,4^{\prime \prime}$ north & $\begin{array}{l}100 \mathrm{~m} \text { in front of coral reefs, more than } 40 \\
\text { m deep }\end{array}$ & $\begin{array}{l}\text { August, } 8 \\
2019\end{array}$ & $\begin{array}{l}\text { August, 9 } \\
2019\end{array}$ \\
\hline
\end{tabular}

Measurements were made in sunny weather conditions with wind speeds of less than 2 $\mathrm{km} /$ hour. Measurement of air temperature in the vertical direction is carried out at a position of $5 \mathrm{~cm}, 20 \mathrm{~cm}, 50 \mathrm{~cm}, 1 \mathrm{~m}, 2 \mathrm{~m}$ above the water surface. Water temperature measurements were carried out at a depth of $5 \mathrm{~cm}, 25 \mathrm{~cm}, 50 \mathrm{~cm}, 150 \mathrm{~cm}$, and $5 \mathrm{~m}$ below the surface. For this measurement depth range, the measured water temperature data is bulk SST. Sea water temperature measurements are carried out in half-moon conditions where the tides fluctuate minimally. Measurements were taken every 2 hours for 24 hours. The water temperature was measured using a flow watch kit 1 , with a precision of $0.1^{\circ} \mathrm{C}$ and a temperature range of $-50^{\circ} \mathrm{C}$ to $100^{\circ} \mathrm{C}$. this device is also used to measure and control the speed of the flow. Air temperature is measured using a 4 in 1 instrument that simultaneously measures air temperature, wind speed, humidity and light intensity. The temperature measurement precision is $0.1^{\circ} \mathrm{C}$. This tool is also used to control wind speed

\section{Results}

The data measured at each location is arranged in a matrix form, based on time and position. The data analysis followed the TGDDA parameter analysis stages. The results of the analysis of air and water temperatures dynamic show the highest and lowest temperatures. The highest temperatures at the six locations occurred between $1 \mathrm{pm}$ and 2:30 pm. The highest air and water temperatures at location- 1 were $26.8^{\circ} \mathrm{C}$ and $26.5^{\circ} \mathrm{C}$. At location-2, the highest air and water temperatures were $27.5^{\circ} \mathrm{C}$ and $27.2^{\circ} \mathrm{C}$. At location-3, the highest air and water temperatures were $29.2^{\circ} \mathrm{C}$ and $28.6^{\circ} \mathrm{C}$. At location-4, the highest air and water temperatures were $30.4^{\circ} \mathrm{C}$ and $29.5^{\circ} \mathrm{C}$. At location-5, the highest air and water temperatures were $32.2^{\circ} \mathrm{C}$ and $31.2^{0} \mathrm{C}$. At location-6, the highest air and water temperatures were $32.3^{\circ} \mathrm{C}$ and $31^{\circ} \mathrm{C}$. The lowest air and water temperature occurs when the thermal equilibrium between air and water is reached. In the thermal equilibrium time interval, the temperature of air and water is the same. At locations-1 and 2, the lowest air and water temperatures were $22.2^{\circ} \mathrm{C}$ and $22.8^{\circ} \mathrm{C}$. At locations 3 and 4 , the lowest air and water temperatures were $23.8^{\circ} \mathrm{C}$ and $24.4^{\circ} \mathrm{C}$. At locations 5 and 6 , the lowest air and water temperatures were $25.7^{\circ} \mathrm{C}$ and $25.9^{\circ} \mathrm{C}$.

Figure- 4 presents a graph of the daily dynamics of the gradient of air temperature and water temperature at locations 1 and 2. Figure-5 presents a graph of the daily dynamics of the gradient of air and water temperatures at locations 3 and 4. Figure- 6 presents a graph of the daily dynamics of the gradient of air and water temperature at locations 5 and 6 . The grouping of two graphs in one image is to compare the two locations that have ecological similarities. From each image, the dynamics of the gradient and the thermal interaction between air and water can be compared. 


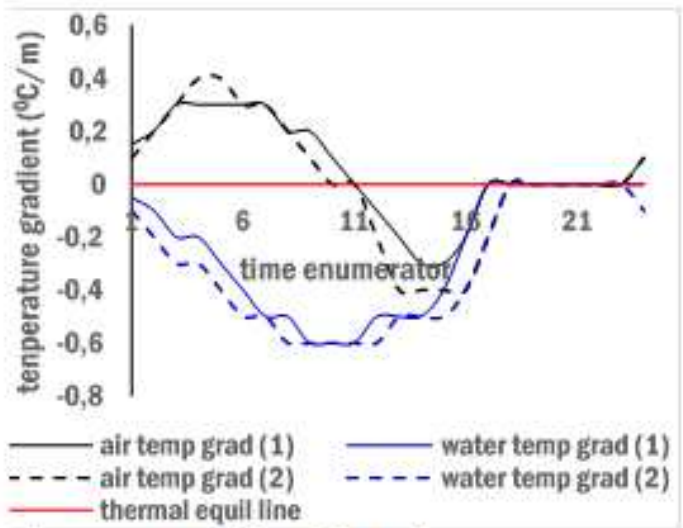

Figure-4. Graphic of air and water temperature gradient at location 1 and 2

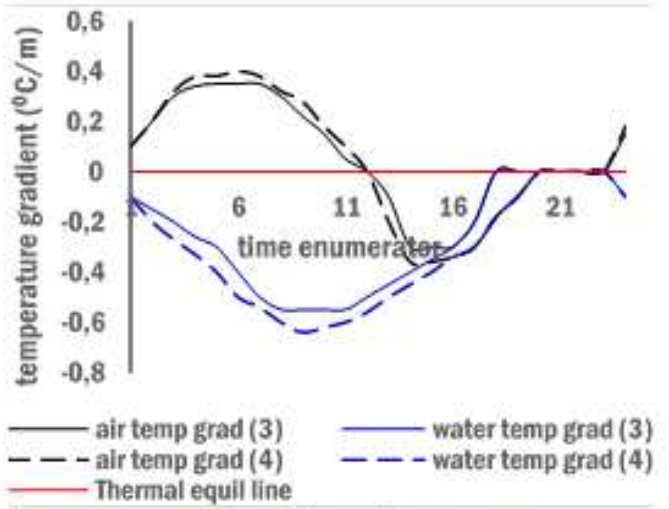

Figure-5. Graphic of air and water temperature gradient at location 3 and 4

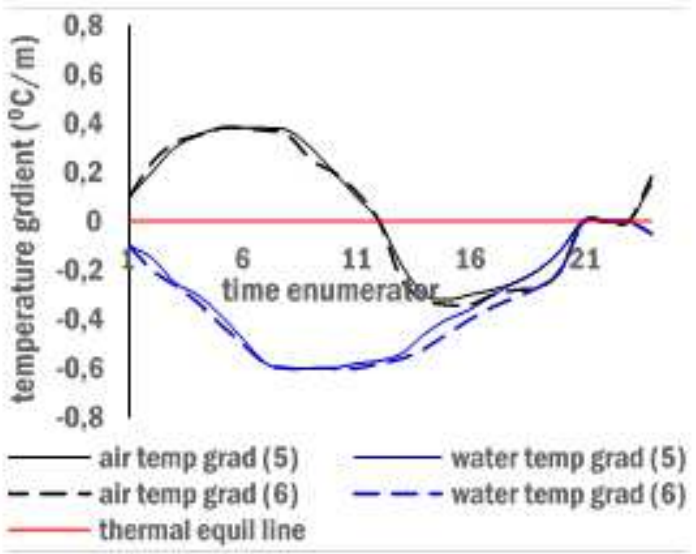

Figure-6. Graphic of air and water temperature gradient at location 5 and 6

Figures-4, 5, and 6 show that the daily dynamics of the air temperature gradient form two dynamic fields, above and below the thermal equilibrium line. The daily dynamics of the water temperature gradient form only one dynamic plane which lies below the line of thermal equilibrium. The daily dynamics of the gradient of air and water temperatures show a time span where the gradient has a value of zero. Conditions where the gradient has a zero value indicates that the air is homogeneous and there is no thermal flow between layers in the vertical direction. The same conditions apply to water. To interpret in detail, Figure-7 presents a daily dynamic graph of air and water temperature at the top, and a graph of daily dynamics of air and water temperature gradient at the bottom. 


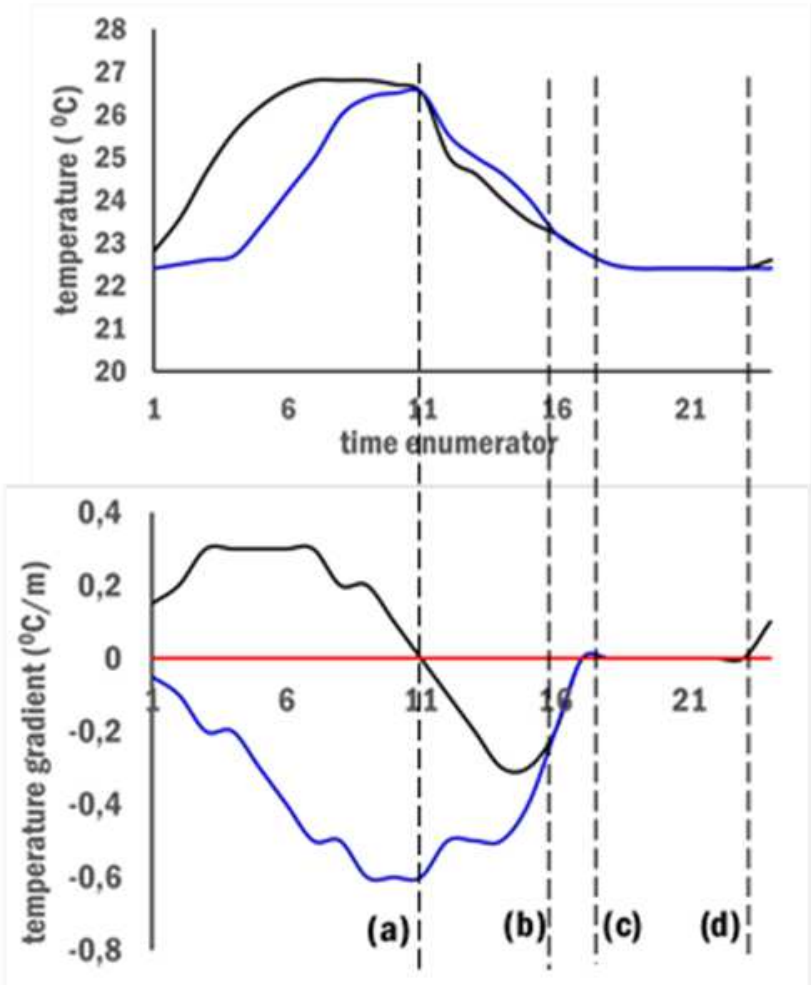

Figure-7. Gradient dynamics and daily changes of water and air temperature, location-1

Figure-7 is equipped with four vertical dotted lines, namely lines (a), (b), (c) and (d). These lines connect certain positions on the dynamic graph of air and water temperature at the top with the gradient graph of air and water temperature at the bottom. These four vertical lines divide the gradient dynamic graph of air temperature into four gradient dynamics zones: (a) (b), (b) - (c), (c) - (d) and ((d) - (a). For the water, there are only two gradient dynamic zones, namely (c) - (d) and (d) - (c). The explanation of the daily gradient dynamic zone is as follows:

1) Zone (a) - (b), is a zone where the air temperature becomes lower than the water temperature as shown in the upper part of Figure-7. Figure-7 shows line (a) lies at the intersection of the curve of the change of air temperature with the water temperature. At the bottom of Figure7 , line (a) is the intersection of the air temperature gradient curve with the thermal equilibrium line. Line (a) is the limit of change of air temperature gradient direction, from positive or above the thermal equilibrium line to negative or below the thermal equilibrium line. The interpretation of air and water temperature gradient graph in zones (a) - (b) concludes that the air temperature near the water surface is higher than the layer above it, and the water temperature in the layer near the subskin-bulk SST boundary is higher than the layer below. Zone (a) - (b) occurs between 4:02 pm and 8:55 pm, with a duration of 4 hours 53 minutes.

2) Zone (b) - (c), is a zone where the temperature of air and water in the layer near the boundary becomes the same, as shown in the graphic at the top of Figure-7. In this zone, the gradient of air and water temperature is the same, but the values are not zero. In this zone, the air temperature in the layer near the water surface is higher than the layer above it. The water temperature in the layer near the skin-bulk SST boundary is higher than the water temperature in the lower layer. In this zone, no thermal energy received from solar irradiation. The air layer near the water surface gets its thermal energy supply from the water. In zones (b) - (c) the water and air temperatures fall by the same value. The gradient of air and water temperature has the same value and continues to fall until it becomes zero at 
line position (c). For location-1, the duration of the gradient dynamics in zone (b) - (c) is 57 minutes, which is between 8:55 pm and 9:52 pm.

3) Zone (c) - (d) is a zone where air and water temperatures are the same. In this zone the gradient of air and water temperature is zero. The temperature of the air in the near water surface layer is the same with the layer above it. The temperature of the water near the boundary of subskin-bulk SST is the same with the layer below it. In this zone the temperature of air and water is $22.50 \mathrm{C}$. Air and water are in thermal equilibrium. For location-1, the duration of the air-water thermal equilibrium is 7 hours 36 minutes, between 9:52 pm and 05:28 am

4) Zone (d) - (a) is a zone where air and water are affected by solar radiation. The air temperature began to change at 05:28, while the water temperature began to change at 05:34. In this zone, the air temperature gradient is positive while the water temperature gradient is negative. The air temperature near the water surface is lower than the air temperature in the upper layer. Water temperature near the subskin-bulk SST boundary is higher than the temperature of the water below it. For air temperature gradient, the width of this zone is 11 hours 5 minutes, from 05:28 am to 4:02 am. For water temperature gradient, the zone width (d) - (a) + zone (a) - (b) + zone (b) - (c) is 16 hours 18 minutes, from 05:34 am to 9:52 pm. From line (a) to line (c) the water temperature gradient continues to decrease until it becomes zero at 9:52 $\mathrm{pm}$. There are only two water temperature gradient dynamic zones, from (d) to (c) and from (c) to (d). The width of the dynamic zone of the air and water temperature gradient is not the same between the study locations. This is of course a characteristic of the waters of the research location.

Figures-4, 5, and 6 show the same dynamic gradient pattern of air and water temperatures throughout the day. The air temperature gradient has a positive gradient located above the thermal equilibrium line, and a negative gradient located below the thermal equilibrium line. A positive air temperature gradient shows the direction of the thermal flux from above to the air layer near the water surface. The negative gradient shows the direction of thermal flux from the air layer near the water surface to the above layer. Water temperature gradient only has a negative gradient which shows the thermal flux from the subskin-bulk SST boundary to the layer below it. The horizontal gradient dynamic graph is a phase of thermal equilibrium where there is no thermal flux between layers of air, between layers of water and between air and water.

The zoning of the dynamics of air and water temperature gradients for the six research locations is presented in Table-2. Table- 2 also presents the area of daily dynamics gradient of air and water temperature for the six study sites. For locations 1, 2, 5, and 6, there are two groups of data obtained from measurements in two consecutive days. Comparison between research locations concluded that the four dynamic zoning occurred at different times and with different durations. Referring to the conditions of the research location presented in Table-1, it can be interpreted that the factors affecting the gradient dynamics zone are solar radiation and fresh water supply. The duration of zones (a) - (b), zones (b) - (c) and zones (d) - (a) is associated with the area of the daily dynamic of air and water temperatures. This area of daily gradient dynamics also differs between locations such as the time difference and duration of each gradient dynamics zone 
Table-2, Summary of dynamic analysis and the area of daily dynamics gradient of air and water temperature at six locations

\begin{tabular}{|c|c|c|c|c|c|c|c|c|c|c|c|}
\hline \multicolumn{12}{|c|}{ The dynamic of air and water temperature gradient } \\
\hline \multirow{3}{*}{$\begin{array}{c}\text { Zona of } \\
\text { dynamic } \\
\text { gradient }\end{array}$} & \multirow{3}{*}{$\begin{array}{c}\text { Air/ } \\
\text { water }\end{array}$} & \multicolumn{10}{|c|}{ Time and duration of gradient dynamic at six locations (first and second measurement for location $1,2,5,6$ ) } \\
\hline & & \multicolumn{2}{|c|}{ Location-1 } & \multicolumn{2}{|c|}{ Location-2 } & \multirow{2}{*}{$\begin{array}{c}\text { Location } \\
3\end{array}$} & \multirow{2}{*}{$\begin{array}{c}\text { Location- } \\
4\end{array}$} & \multicolumn{2}{|c|}{ Location -5} & \multicolumn{2}{|c|}{ Location-6 } \\
\hline & & I & II & I & II & & & I & II & I & II \\
\hline \multirow[t]{2}{*}{ (a)-(b) } & air & $\begin{array}{l}4: 02 \mathrm{pm}- \\
8: 55 \mathrm{pm}\end{array}$ & $\begin{array}{l}4: 00 \mathrm{pm}- \\
8: 54 \mathrm{pm}\end{array}$ & $\begin{array}{l}3: 58 \mathrm{pm}- \\
9: 12 \mathrm{pm}\end{array}$ & $\begin{array}{l}3: 55 \mathrm{pm}- \\
9: 10 \mathrm{pm}\end{array}$ & $\begin{array}{l}4: 58 \mathrm{pm}- \\
9: 15 \mathrm{pm}\end{array}$ & $\begin{array}{l}4: 55 \mathrm{pm}- \\
9: 00 \mathrm{pm}\end{array}$ & $\begin{array}{l}5: 15 \mathrm{pm}- \\
10: 42 \mathrm{pm} \\
\end{array}$ & $\begin{array}{l}5: 13 \mathrm{pm}- \\
10: 42 \mathrm{pm}\end{array}$ & $\begin{array}{l}5: 14 \mathrm{pm}- \\
11: 48 \mathrm{pm}\end{array}$ & $\begin{array}{l}5: 15 \mathrm{pm}- \\
11: 46 \mathrm{pm}\end{array}$ \\
\hline & & $\begin{array}{l}4 \text { hours } 53 \\
\text { min }\end{array}$ & $\begin{array}{l}4 \text { hours } 54 \\
\text { min }\end{array}$ & $\begin{array}{l}5 \text { hours } 14 \\
\text { min }\end{array}$ & $\begin{array}{l}5 \text { hours } 15 \\
\text { min }\end{array}$ & $\begin{array}{l}4 \text { hours } \\
17 \text { min } \\
\end{array}$ & $\begin{array}{l}4 \text { hours } 5 \\
\min \end{array}$ & $\begin{array}{l}5 \text { hours } 27 \\
\text { min }\end{array}$ & $\begin{array}{l}5 \text { hours } 29 \\
\text { min }\end{array}$ & $\begin{array}{l}6 \text { hours } 34 \\
\text { min }\end{array}$ & $\begin{array}{l}6 \text { hours } 31 \\
\text { min }\end{array}$ \\
\hline \multirow[t]{2}{*}{ (b)-(c) } & air & $\begin{array}{l}8: 55 \mathrm{pm}- \\
9: 52 \mathrm{pm}\end{array}$ & $\begin{array}{l}8: 54 \mathrm{pm}- \\
9: 52 \mathrm{pm}\end{array}$ & $\begin{array}{l}9: 12 \mathrm{pm}- \\
10: 48 \mathrm{pm}\end{array}$ & $\begin{array}{l}9: 10 \mathrm{pm}^{-} \\
10: 42 \mathrm{pm}\end{array}$ & $\begin{array}{l}9: 15 \mathrm{pm}- \\
11: 02 \mathrm{pm}\end{array}$ & $\begin{array}{l}\text { 9:00 pm- } \\
\text { 0:05 am }\end{array}$ & $\begin{array}{l}10: 42 \mathrm{pm} \\
-1: 58 \mathrm{am}\end{array}$ & $\begin{array}{l}10: 42 \mathrm{pm}- \\
1: 56 \mathrm{am}\end{array}$ & $\begin{array}{l}11: 48 \mathrm{pm}- \\
1: 58 \mathrm{am}\end{array}$ & $\begin{array}{l}11: 46 \mathrm{pm}- \\
1: 57 \mathrm{am}\end{array}$ \\
\hline & & 57 min. & $58 \mathrm{~min}$ & $\begin{array}{l}1 \text { hour } 36 \\
\text { min }\end{array}$ & $\begin{array}{l}1 \text { hour } 32 \\
\text { min }\end{array}$ & $\begin{array}{l}1 \text { hour } 47 \\
\min \end{array}$ & $\begin{array}{l}3 \text { hours } 5 \\
\text { min }\end{array}$ & $\begin{array}{l}3 \text { hours } 16 \\
\text { min }\end{array}$ & $\begin{array}{l}3 \text { hours } 14 \\
\text { min }\end{array}$ & $\begin{array}{l}2 \text { hours } 10 \\
\text { min }\end{array}$ & $\begin{array}{l}2 \text { hours } 11 \\
\text { min }\end{array}$ \\
\hline \multirow[t]{4}{*}{ (c)-(d) } & air & $\begin{array}{l}9: 52 \mathrm{pm}- \\
05: 28 \mathrm{am}\end{array}$ & $\begin{array}{l}\text { 9:52 } \mathrm{pm}- \\
05: 26 \mathrm{am}\end{array}$ & $\begin{array}{l}10: 48 \mathrm{pm}- \\
05: 23 \mathrm{am}\end{array}$ & $\begin{array}{l}10: 42 \mathrm{pm} \\
05: 22 \mathrm{am}\end{array}$ & $\begin{array}{l}\text { 11:02 pm- } \\
\text { 05:20 am }\end{array}$ & $\begin{array}{l}0: 05 \mathrm{am}- \\
05: 20 \mathrm{am}\end{array}$ & $\begin{array}{l}1: 58 \mathrm{am}- \\
05: 18 \mathrm{am}\end{array}$ & $\begin{array}{l}1: 56 \mathrm{am}- \\
05: 19 \mathrm{am}\end{array}$ & $\begin{array}{l}1: 58 \mathrm{am}- \\
05: 17 \mathrm{am}\end{array}$ & $\begin{array}{l}1: 27 \mathrm{am}- \\
05: 18 \mathrm{am}\end{array}$ \\
\hline & & $\begin{array}{l}7 \text { hours } 36 \\
\text { min }\end{array}$ & $\begin{array}{l}7 \text { hours } 34 \\
\text { min }\end{array}$ & $\begin{array}{l}6 \text { hours } 35 \\
\min \end{array}$ & $\begin{array}{l}6 \text { hours } 40 \\
\text { min }\end{array}$ & $\begin{array}{l}6 \text { hours } \\
18 \mathrm{~min}\end{array}$ & $\begin{array}{l}5 \text { hours } 15 \\
\text { min }\end{array}$ & $\begin{array}{l}3 \text { hours } 20 \\
\text { min }\end{array}$ & $\begin{array}{l}3 \text { hourrs } \\
23 \text { min }\end{array}$ & $\begin{array}{l}3 \text { hours } 19 \\
\text { min }\end{array}$ & $\begin{array}{l}3 \text { hours } 21 \\
\text { min }\end{array}$ \\
\hline & water & $\begin{array}{l}9: 52 \mathrm{pm}- \\
05: 34 \mathrm{am}\end{array}$ & $\begin{array}{l}9: 50 \mathrm{pm}- \\
05: 32 \mathrm{am}\end{array}$ & $\begin{array}{l}10: 50 \mathrm{pm}- \\
05: 00 \mathrm{am}\end{array}$ & $\begin{array}{c}10: 48 \mathrm{pm} \\
-5: 05 \mathrm{am}\end{array}$ & $\begin{array}{l}11: 15 \mathrm{pm}- \\
5: 22 \mathrm{am}\end{array}$ & $\begin{array}{l}0: 48 \mathrm{am}- \\
5: 22 \mathrm{am}\end{array}$ & $\begin{array}{l}2: 00 \mathrm{am}- \\
5: 20 \mathrm{am}\end{array}$ & $\begin{array}{l}1: 58 \mathrm{am} \\
5: 19 \mathrm{am}\end{array}$ & $\begin{array}{l}1: 58 \mathrm{am}^{-} \\
4.58 \mathrm{am}\end{array}$ & $\begin{array}{l}1: 58 \mathrm{am}- \\
\text { 5:00 am }\end{array}$ \\
\hline & & $\begin{array}{l}7 \text { hours } 42 \\
\text { min }\end{array}$ & $\begin{array}{l}7 \text { hours } 42 \\
\text { min }\end{array}$ & $\begin{array}{l}6 \text { hours } 10 \\
\min \end{array}$ & $\begin{array}{l}6 \text { hours } 17 \\
\text { min }\end{array}$ & $\begin{array}{l}6 \text { hours } 7 \\
\text { min }\end{array}$ & $\begin{array}{l}4 \text { hours } 34 \\
\text { min }\end{array}$ & $\begin{array}{l}3 \text { hours } 20 \\
\text { min }\end{array}$ & $\begin{array}{l}3 \text { hours } 21 \\
\text { min }\end{array}$ & 3 hours & $\begin{array}{l}3 \text { hours } 2 \\
\text { min }\end{array}$ \\
\hline \multirow[t]{3}{*}{ (d)-(a) } & air & $\begin{array}{l}05: 28 \mathrm{am} \\
-4.02 \mathrm{pm}\end{array}$ & $\begin{array}{l}05: 26 \mathrm{am}- \\
4.00 \mathrm{pm}\end{array}$ & $\begin{array}{l}05: 23 \mathrm{am}- \\
3: 58 \mathrm{pm}\end{array}$ & $\begin{array}{l}05: 22 \mathrm{am} \\
-3: 55 \mathrm{pm}\end{array}$ & $\begin{array}{l}05: 20 \mathrm{am} \\
-4: 58 \mathrm{pm}\end{array}$ & $\begin{array}{l}05: 20 \mathrm{am} \\
-455 \mathrm{pm}\end{array}$ & $\begin{array}{l}05: 18 \mathrm{am} \\
-5: 15 \mathrm{pm}\end{array}$ & $\begin{array}{l}05: 19 \mathrm{am} \\
-5: 13 \mathrm{pm}\end{array}$ & $\begin{array}{l}05: 17 \mathrm{am}- \\
5: 14 \mathrm{pm}\end{array}$ & $\begin{array}{l}05: 18 \mathrm{am}- \\
5: 15 \mathrm{pm}\end{array}$ \\
\hline & & 10 hours & 10 hours & 10 hours & 10 hours & 11 hours & 11 hours & 11 hours & 11 hours & 11 hours 57 & 11 hours 57 \\
\hline & & $34 \mathrm{~min}$ & $34 \mathrm{~min}$ & $35 \mathrm{~min}$ & & & & & & & $\min$ \\
\hline \multirow[t]{3}{*}{ (d)-(c) } & water & $\begin{array}{l}05.34 \mathrm{am} \\
-9: 52 \mathrm{pm}\end{array}$ & $\begin{array}{l}05: 32 \mathrm{am}^{-} \\
9: 50 \mathrm{pm}\end{array}$ & $\begin{array}{l}05: 00 \mathrm{am}- \\
10: 50 \mathrm{pm}\end{array}$ & $\begin{array}{l}5: 05 \mathrm{am}- \\
10: 48 \mathrm{pm}\end{array}$ & $\begin{array}{l}5: 22 \mathrm{am}- \\
11: 15 \mathrm{pm}\end{array}$ & $\begin{array}{l}5: 22 \mathrm{am}- \\
0: 48 \mathrm{am}\end{array}$ & $\begin{array}{l}5: 20 \mathrm{am}- \\
2: 00 \mathrm{am}\end{array}$ & $\begin{array}{l}5-19 \mathrm{am}- \\
1: 58 \mathrm{am}\end{array}$ & $\begin{array}{l}4: 58 \mathrm{am}- \\
1: 58 \mathrm{am}\end{array}$ & $\begin{array}{l}5: 00 \mathrm{am}- \\
158 \mathrm{am}\end{array}$ \\
\hline & & 16 hours & 16 hours & 17 hours & 17 hours & 17 hours & 19 hours & 20 hours & 20 hours & 21 hours & 20 hours 58 \\
\hline & & $18 \mathrm{~min}$ & $18 \mathrm{~min}$ & $50 \mathrm{~min}$ & & $53 \mathrm{~min}$ & 261 & & & & \\
\hline \multicolumn{12}{|c|}{ The area of temperature gradient dynamic $\left({ }^{0} \mathrm{C}\right.$. hours $\left./ \mathrm{m}\right)$} \\
\hline \multirow[t]{2}{*}{ air } & Above & 2.42 & 2,40 & 2,4 & 2,4 & 2,86 & 2,94 & 3,2 & 3,2 & 3,24 & 3,26 \\
\hline & Below & 1.14 & 1,17 & 1,23 & 1,22 & 1,3 & 1,74 & 1,83 & 1,84 & 2,29 & 2,30 \\
\hline Water & Below & 6,15 & 6,13 & 7,42 & 7,4 & 6,92 & 7,78 & 7,92 & 7,94 & 8,49 & 8,52 \\
\hline
\end{tabular}




\section{Discussion}

The consistency of the results of data analysis measured on two consecutive days with the same weather conditions, shows that the daily dynamic analysis method of water-air thermal interaction and TGDDA parameters can be used to characterize the local conditions of the aquatic ecosystem. The difference in the duration of the air-water thermal interaction zone and the TGDDA parameter between two adjacent measurement positions but having different ecological conditions, indicates that these parameters are sensitive to be used in a local scale analysis. The difference in the duration of the thermal interaction zone and the parameter values of TGDDA locations- 1 and 2 is influenced by: the duration of exposure and the presence of fresh water supply. The duration of direct irradiation at location-1 is only around 7 hours 40 minutes due to hillside shade, while at location 2 it is around 10 hours 50. The conclusion from the comparison analysis results of locations-3 and 4 is the same as the comparison of locations- 1 and 2 . The effect of fresh water supply on thermal energy in water and air-water thermal flux, among others, was stated by Sim et al (2017). The effect of intensity and duration of irradiation on themal energy storage in water was stated by Wang et al (2019). Furthermore, thermal energy storage in water determines the thermal flux from water to air (Sarbu and Sebarchievici, 2018; Shinoda et al, 2019).

Comparison of locations 5 and 6 shows that the sea water depth factor causes differences in the zoning duration of thermal interactions and TGDDA. Location-6 is deeper and can store more thermal energy than location-5 which is shallower. These results are in accordance with the results of research by Wang et al (2019) which states that depth will affect the eddy exchange below the surface which ultimately affects the thermal flux exchange between air and water. These results indicate that the local analysis of air-water thermal interactions guarantees more detailed information. Yu (2019) suggests that direct measurements of air-water thermal flux can only be carried out for limited or local locations. Graf (2019) suggests that the analysis of the relationship between irradiation and thermal storage in water must be carried out in detail both spatially and temporally. For ecosystem analysis and utilization of coastal waters and lakes resources, detailed local scale information is needed, resulting from in situ measurements (Shinoda et al, 2019). The local air-water thermal interaction analysis method and TGDDA parameters become a reference for a comprehensive ecosystem analysis. Research outputs at six locations become the basis for research development related to variations in water chemistry conditions and aquatic biota.

\section{Conclusion}

The air-water thermal interaction time zoning method and the TGDDA parameter can characterize the air-water thermal interaction conditions on a local scale. variations in the duration of the interaction zone and the magnitude of TGDDA between locations, proving that local ecological factors influence air-water thermal interactions. The dominant factors affecting the difference in the duration of the interaction zone and TGDDA are the duration of irradiation, the presence of fresh water supply and water depth.

\section{Acknowledgment}

The author would like to thank the Director General of Higher Education who has funded a series of related studies. Thanks are given to the natural resources and environment group research team for their input through the discussion. Awards and gratitude to students of the Department of Physics, Faculty of Mathematics and Natural Sciences, Manado State University who have participated in field measurement activities 


\section{REFERENCES}

Alappattu, D.P., Wang, Q., Yamaguchi, R., Lind, R.J., Reynolds, M. \& Christman, A.J. (2017). Warm layer and cool skin corrections for bulk water temperature measurements for air-sea interaction studies. J. Geophys. Res. Oceans, 122: 6470-6481.

Augyte, S., Yarish, Ch., \& Neefus, Ch.D. (2019). Thermal and light impacts on the early growth stages of the kelp Saccharina angustissima (Laminariales, Phaeophyceae). Algae, 34(2): 153-162 https://doi.org/10.4490/algae.2019.34.5.12

Chu, P.C., \& Fan, C. (2019). Global ocean synoptic thermocline gradient, isothermal-layer depth, and other upper ocean parameters. Sci Data, 6: 119. doi: 10.1038/s41597-019-0125-3

de Bettignies, Th., Wernberg, Th. \& Gurgel, C.F.D. (2018). Exploring the Influence of Temperature on Aspects of the Reproductive Phenology of Temperate Seaweeds. Front. Mar. Sci.. https://doi.org/10.3389/fmars.2018.00218

Feng, X., Hainesa, K. and de Boiss'eson, E. (2018). Coupling of surface air and sea surface temperatures in the CERA-20C reanalysis". Q.J.R.Meteorol.Soc., 144: 195-207.

Ge, X., Wang, W., Kumar, A \& Zhang, Y. (2017). Importance of the Vertical Resolution in Simulating SST Diurnal and Intraseasonal Variability in an Oceanic General Circulation Model". J. Climate, vol. 30(11): 3963-3978.

Graf, R. (2019). A multifaceted analysis of the relationship between daily temperature of river water and air. Acta Geophys. 67, 905-920 https://doi.org/10.1007/s11600-019-00285-3

Kunz, J., \& B Jähne, B. 2018. Investigating Small-Scale Air-Sea Exchange Processes via Thermography. Front. Mech. Eng. https://doi.org/10.3389/fmech.2018.00004

Liu, H., Li, W., Chen, S., Fang, R., \& Li Z. (2018). Atmospheric Response to Mesoscale Ocean Eddies over the South China Sea. Advances in Atmospheric Sciences, 35: 1189-1204,

Maske, H., Ochoa, J., Almeda-Jauregui, C.O, Ruiz-de la Torre, M.C., Cruz-Lopez, R. \& VillegasMendoza, J.R. (2014). Near-surface temperature gradient in a coastal upwelling regime, $J$. Geophys. Res. Oceans, 119: 4972-4982, doi:10.1002/2014JC010074.

Medellu, Ch.S. \& Tulandi, Dj. (2018). Parameter: the area of microclimate gradient giurnal dynamic International Journal of Environment. Agriculture and Biotechnology (IJEAB), vol 3(3): 934-941.

Medellu, Ch. (2019). The plane area of daily dynamics of microclimate gradient. Concepts, methods and application results". International Journal of Applied Science and Technology, 9(3): $18-25$.

Medellu, Ch. (2020). Compatibility between microclimate parameters in the characterization and monitoring of forest ecosystem conditions and environmental interactions. Int. J. Innov. Creat. Chang. 13(7), 273-289.

Osuch, E., Osuch, A., Podsiadłowski, S., Rybacki, P., Adamski, M., \& Ratajczak, J. (2016). Assessment of the condition of Samołęskie Lake waters. Journal of Ecological Engineering, 17 (2): 108-112.

Ptak, M., Tomczyk, A.M. \& Wrzesiński, D. (2018). Effect of teleconnection patterns on changes in water temperature in Polish lakes. Atmosphere, 9: 1-17.

Ptak, M., Sojka, M. \& Nowak, B. (2019). Characteristics of daily water temperature fluctuations in Lake Kierskie (West Poland). Quaestiones Geographicae 38(3), pp. 41-49,

Sarbu, I. \& Sebarchievici, C.A. (2018). Comprehensive Review of Thermal Energy Storage. Sustainability 2018, 10, 191; doi:10.3390/su10010191

Shinoda, T., Zamudio, L., Guo, Y., Metzger, E.J. \& Fairall, Ch.W. (2019). Ocean variability and air-sea fluxes produced by atmospheric rivers. Sci Rep. 9: 2152. doi: 10.1038/s41598-019$38562-2$ 
Sims, R.P., Schuster, U., Watson, A.J., Yang, M.X., Hopkins, F.E, Stephens, J. \& Bell, T.G. (2017). A measurement system for vertical seawater profiles close to the air-sea interface. Ocean Sci.,13:649-660

Solcerova, A., van Emmerik, T., van de Ven, F., Selker, J. \& van de Giesen, N. (2018). Skin effect of fresh water measured using distributed temperature sensing. Water, 10(214), pp 1-12,

Wang, Y., Ma, Q., Gao, Y., Hao, X. \& Liu, S. (2019). Simulation of the Surface Energy Flux and Thermal Stratification of Lake Taihu with Three 1-D Models. Water, 11(5). Doi 10.3390/w11051026

Woolway, R.I., Dokulil, M.T., Marszelewski, W., Schmid, M., Bouffard D. \& Merchant, Ch.J. 2017. Warming of Central European lakes and their response to the 1980s climate regime shift. Climatic Change, 142: 505-520.

Yu, L. (2019). Global Air-Sea Fluxes of Heat, Fresh Water, and Momentum: Energy Budget Closure and Unanswered Questions. Ann Rev Mar Sci 3(11):227-248. doi: 10.1146/annurev-marine-010816-060704. 
Figures

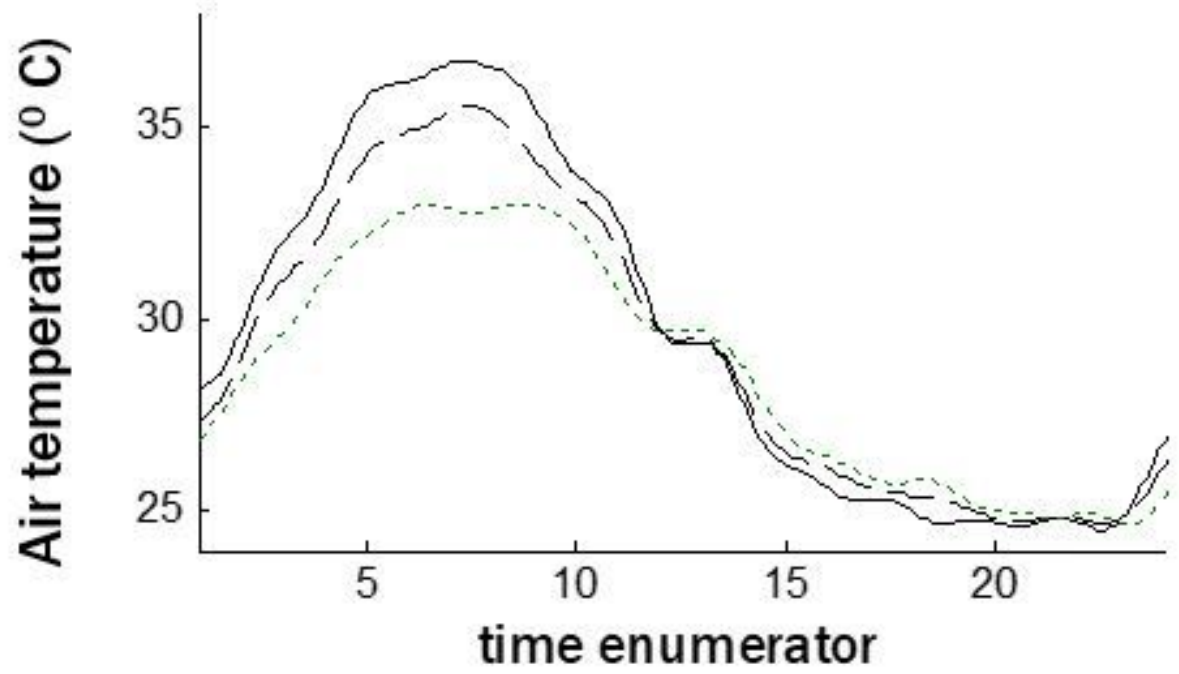

at the edge $16 \mathrm{~m}$ from edge

Figure 1

Example of graphic of temporal function of air temperature: transect-2, mangrove forest - Talengen Bay

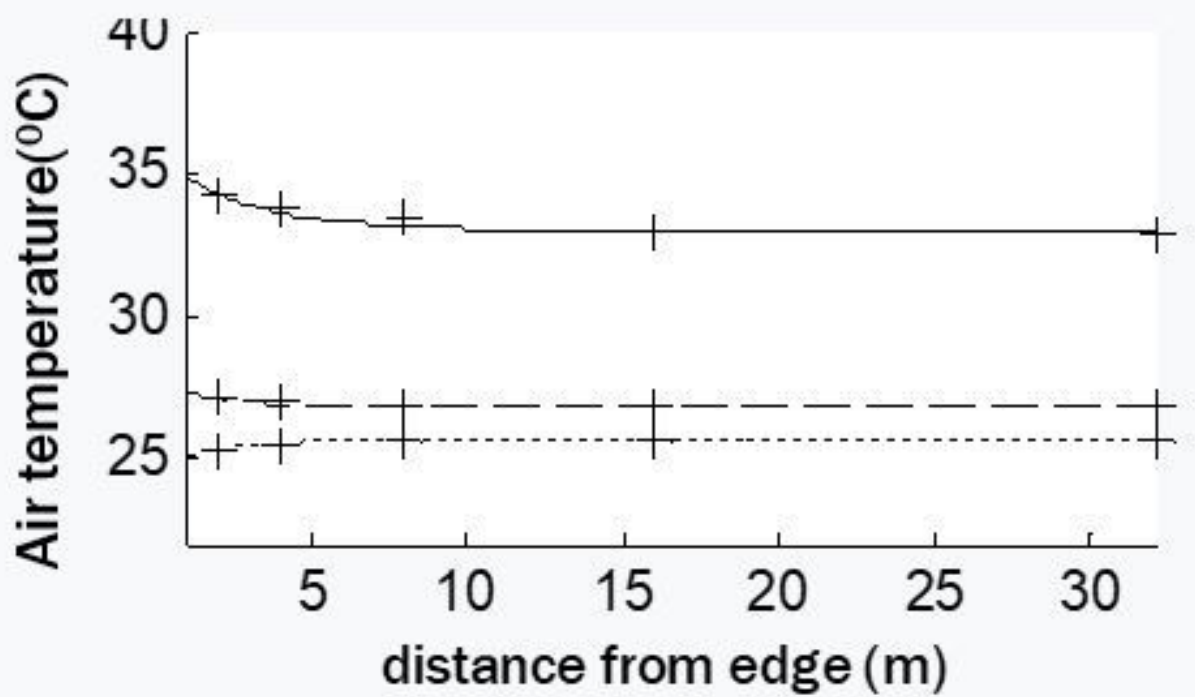

at 6 am

Figure 2

Example of graphic of spatial function of air temperature: transect-2, mangrove forest - Talengen Bay 


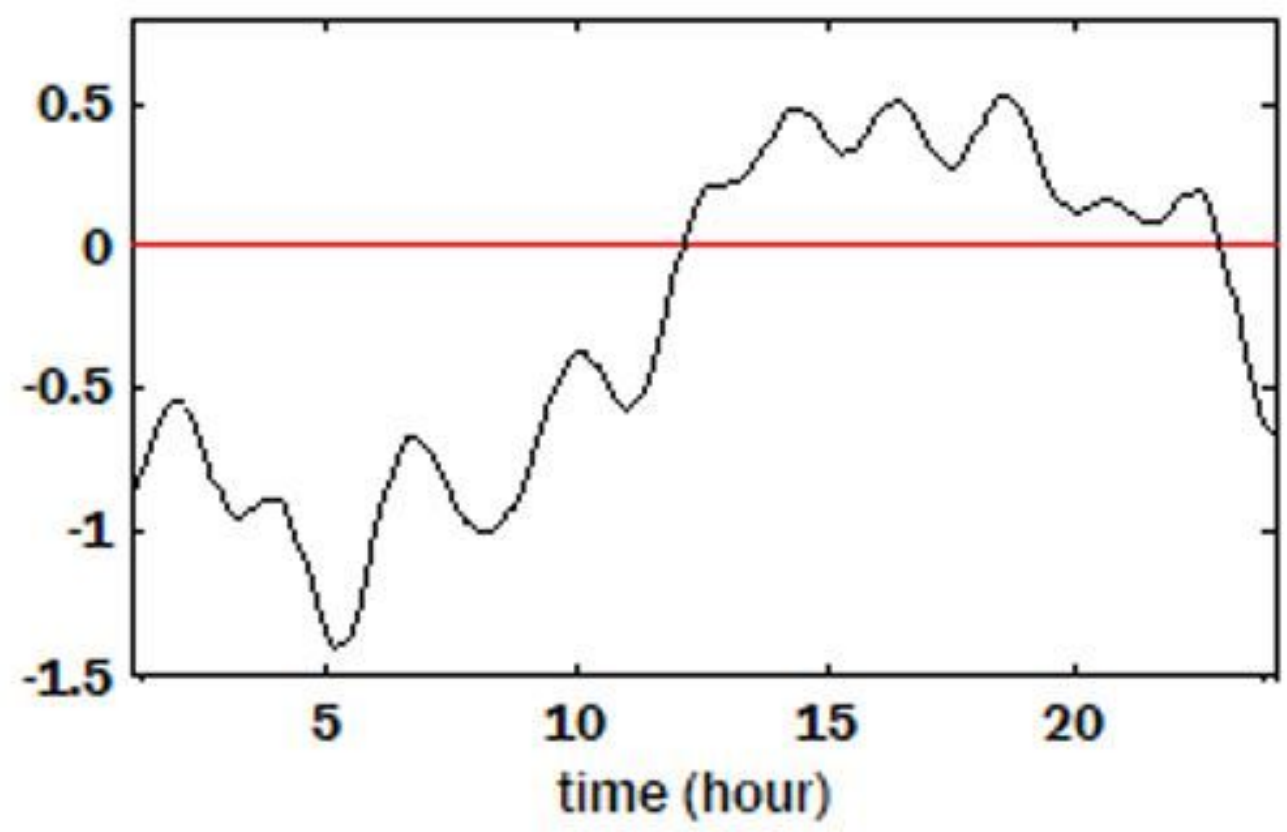

Figure 3

Example of graphic of air temperature gradient dynamic; transect-2, mangrove forest - Talengen Bay
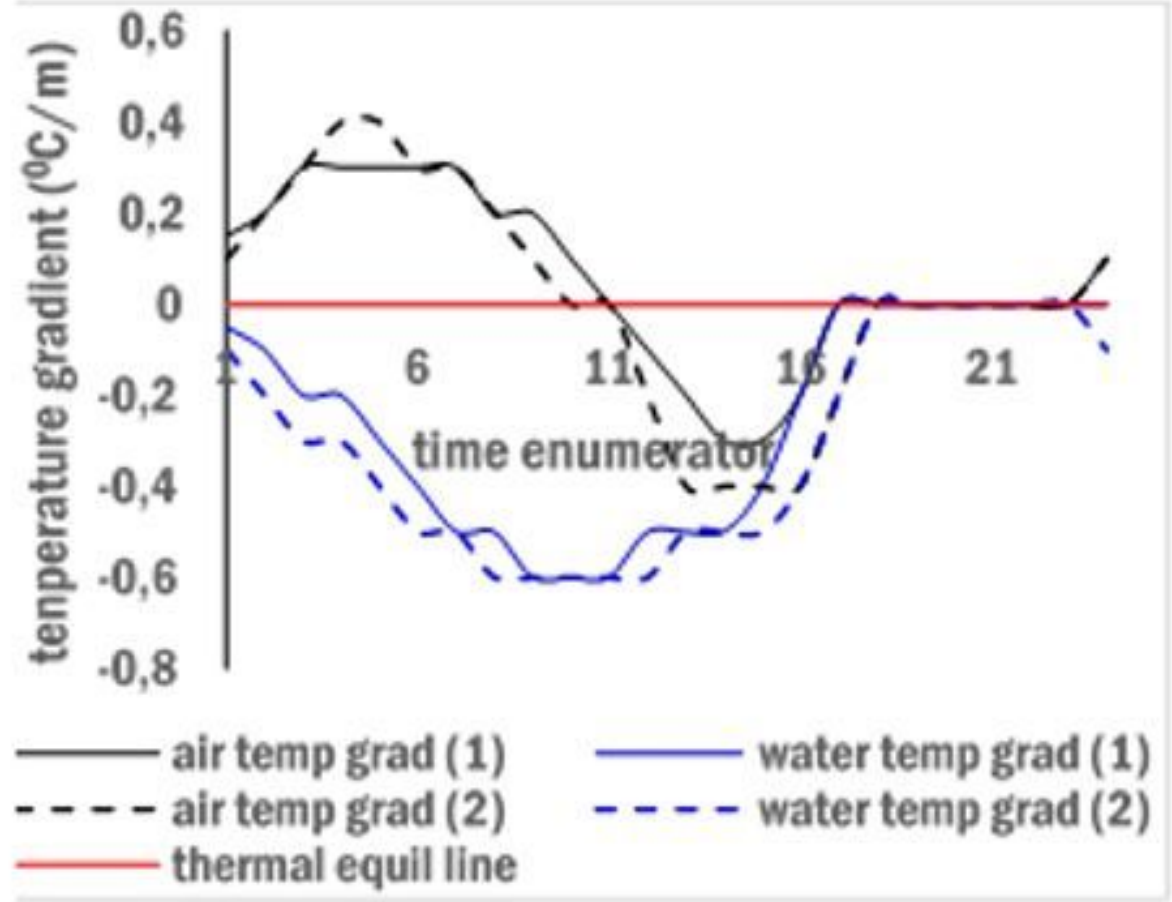

Figure 4

Graphic of air and water temperature gradient at location 1 and 2 

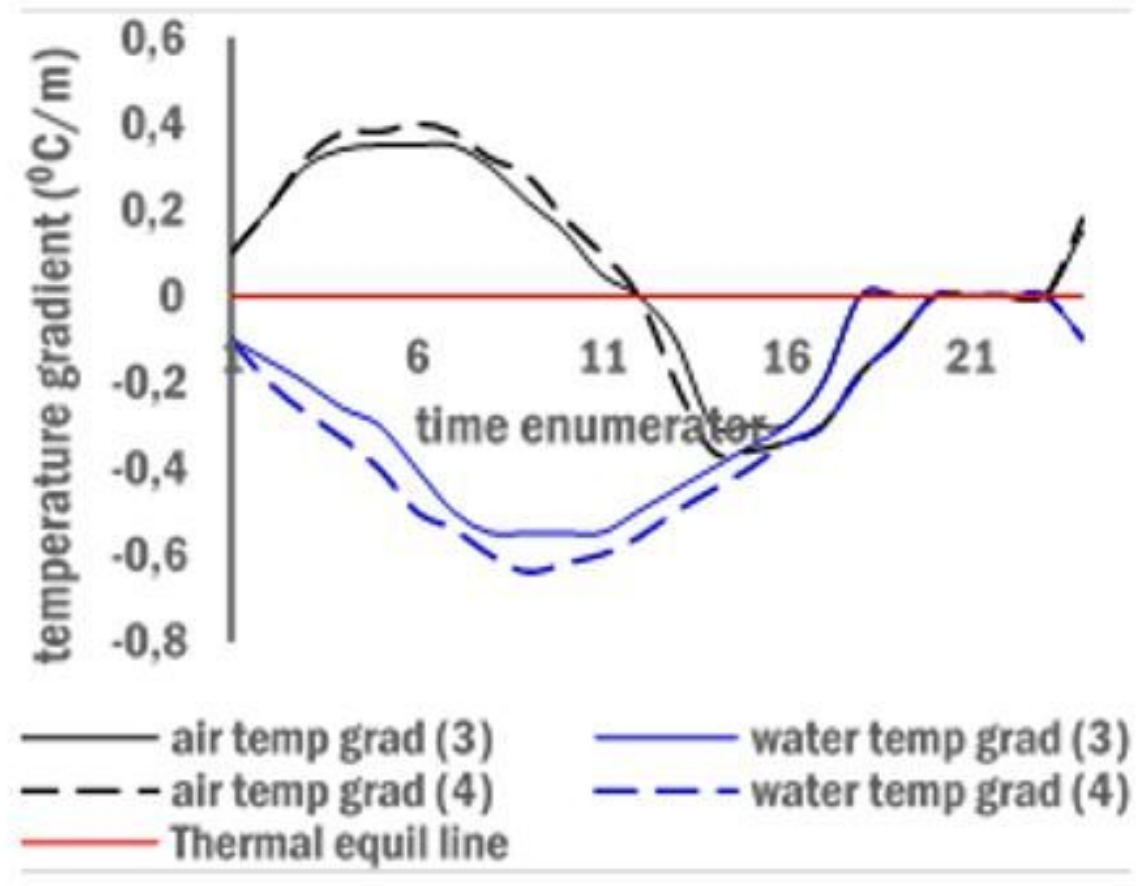

Figure 5

Graphic of air and water tempeature gradient at location 3 and 4

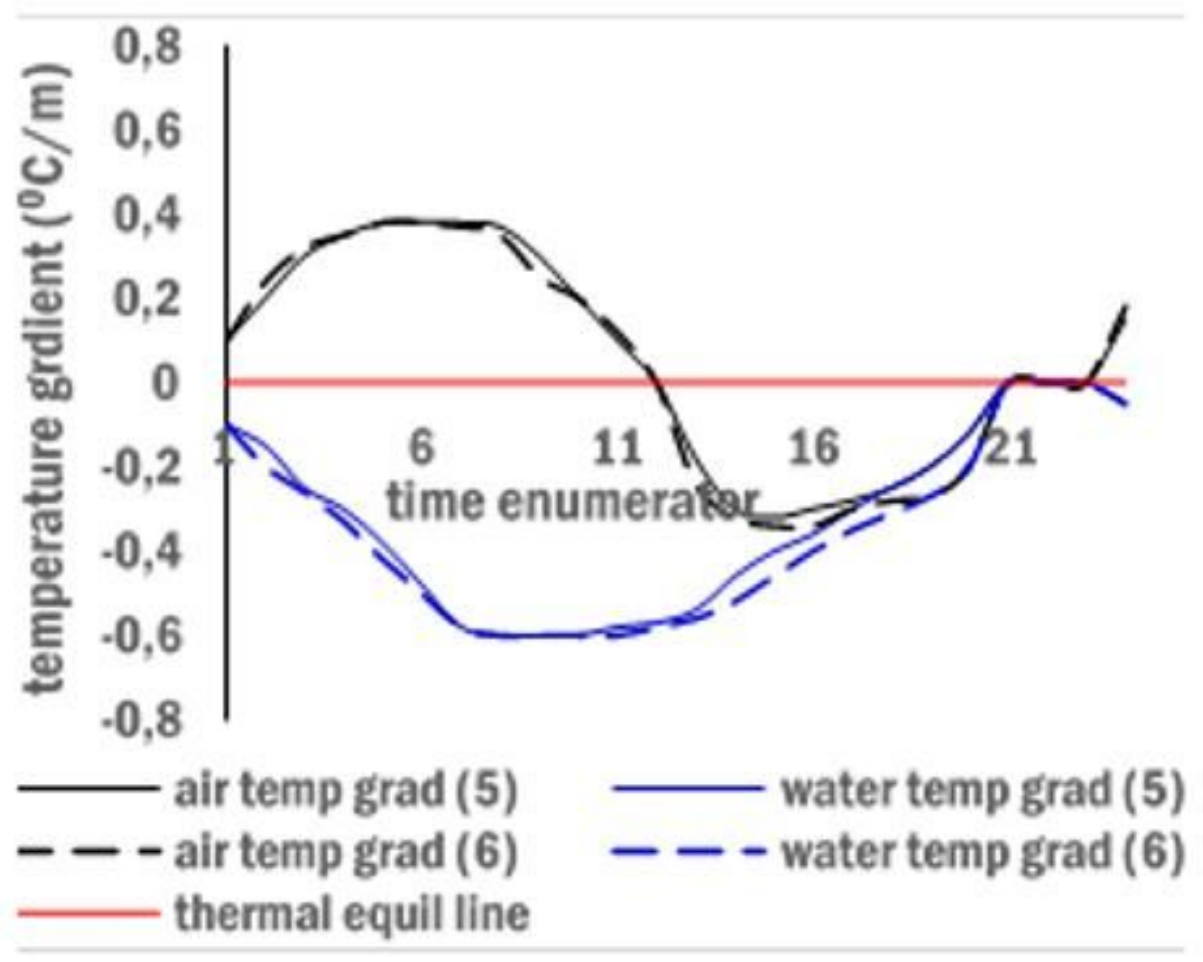

Figure 6

Graphic of air and water temperature gradient at location 5 and 6 


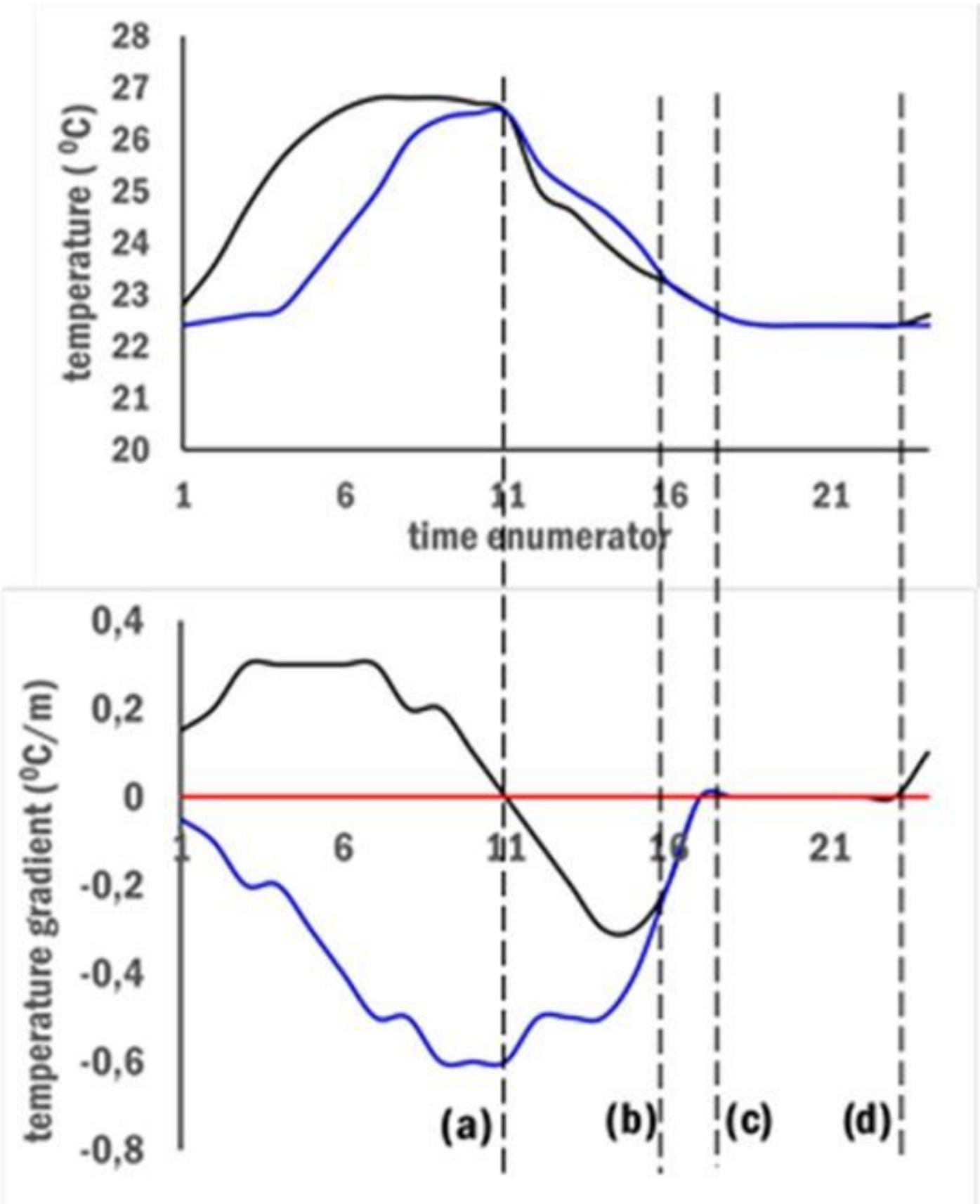

Figure 7

gradient dynamics and daily changes of water and air temperature, location-1 